\title{
Pengaruh Digital Marketing terhadap Peningkatan Kinerja Pemasaran UMKM Pariwisata di Kabupaten Toba Indonesia
}

\author{
Dwita Soave Natio Marbun ${ }^{1}$, Mariana Simanjuntak ${ }^{2}$ \\ ${ }^{1}$ Manajemen Rekayasa, Institut Teknologi Del, Jl. Sisingamangaraja, Laguboti, Indonesia, 22381 \\ Correspondence: Dwita Soave Natio Marbun (dwitasoave@gmail.com) \\ Received: 290721 - Revised: 040821 - Accepted: 080821 - Published: 280921
}

\begin{abstract}
Abstrak. Dilihat dari karakteristik wilayah Indonesia, UMKM sektor pariwisata menjadi salah satu pemegang peran penting dalam pertumbuhan di Indonesia. Akibat dari COVID-19 membuat para pelaku UMKM harus mencari cara agar tetap bertahan dan berkembang. Digital marketing merupakan salah satu soluai dalam meningkatkan pemasaran UMKM di Indonesia. Namun, hasil dari wawancara ke beberapa UMKM Pariwisata di Kabupaten Toba dan juga studi literatur masih ditemukan UMKM yang belum menerapkan digital marketing. Penelitian ini bertujuan untuk melihat ada atau tidaknya pengaruh dari penerapan digital marketing terhadap peningkatan kinerja pemasaran UMKM Pariwisata sebagai acuan bagi pelaku UMKM dalam peningkatan kinerja pemasaran. Hasil dari studi literatur dan wawancara kepada 10 pelaku UMKM yang telah menerapkan digital marketing, variabel yang digunakan pada penelitian ini ialah social media marketing capability, ecommerce adoption, instant messaging orientation, digital marketing dan kinerja pemasaran. Pengumpulan data berupa penyebaran kuesioner cetak dan kuesioner online sebanyak 132 kepada para pelaku UMKM Pariwisata di Kabupaten Toba yang telah menggunakan digital marketing kemudian di analisis menggunakan metode Structural Equation Modeling dengan bantuan software AMOS. Kesimpulan diperoleh bahwa terdapat pengaruh digital marketing terhadap peningkatan kinerja pemasaran UMKM Pariwisata di Kabupaten Toba dan dapat diambil implikasi manajerial sebagai alternatif kebijakan dalam peningkatan kinerja pemasaran UMKM Pariwisata di Kabupaten Toba menggunakan media pemasaran digital.
\end{abstract}

Kata kunci: UMKM Pariwisata, Kinerja Pemasaran, Digital Marketing, Jenis Pemasaran Digital, SEM AMOS

Citation Format: Marbun, D., S., N., Simanjuntak, M. (2020). Pengaruh Digital Marketing Terhadap Peningkatan Kinerja Pemasaran UMKM Pariwisata di Kabupaten Toba Indonesia. Prosiding Seminar Nasional Abdimas Ma Chung (SENAM), 2020, 181-193 


\section{PENDAHULUAN}

Usaha Mikro Kecil dan Menengah (UMKM) merupakan unit usaha produktif yang berdiri sendiri dan dilakukan oleh orang perorangan atau badan usaha disemua sektor ekonomi, seperti yang tertulis pada Undang-Undang No. 20 Tahun 2008 tentang Usaha Mikro Kecil dan Menengah. UMKM berperan penting dalam membantu meningkatkan ekonomi masyarakat di tingkat kota dan kabupaten, hal ini dikarenakan UMKM merupakan entitas produsen sekaligus konsumen yang cukup besar sehingga uang yang ada dimasyarakat mengalami perputaran dari dan oleh UMKM itu sendiri, selain itu UMKM lebih tangguh sehingga lebih tahan terhadap krisis ekonomi dan moneter (Hamzah \& Agustien, 2019).

Saat ini COVID-19 sangat memberikan dampak kepada perekonomian suatu negara. Akibat dari adanya pandemi tersebut perlambatan ekonomi global mulai terjadi dan dirasakan juga oleh Indonesia. Menurut Patimatuzzakrah (2020), dilihat dari karakteristik wilayah Indonesia maka salah satu potensi yang tepat dikembangkan dalam jangka panjang untuk kemakmuran Indonesia ialah pengembangan potensi negara pada sektor pariwisata. Tetapi pada situasi saat ini industri pariwisata di Indonesia terdampak COVID-19. Berikut data pengunjung pada hotel bintang yang ada di Indonesia diambil dari Badan Pusat Statistik (BPS) :

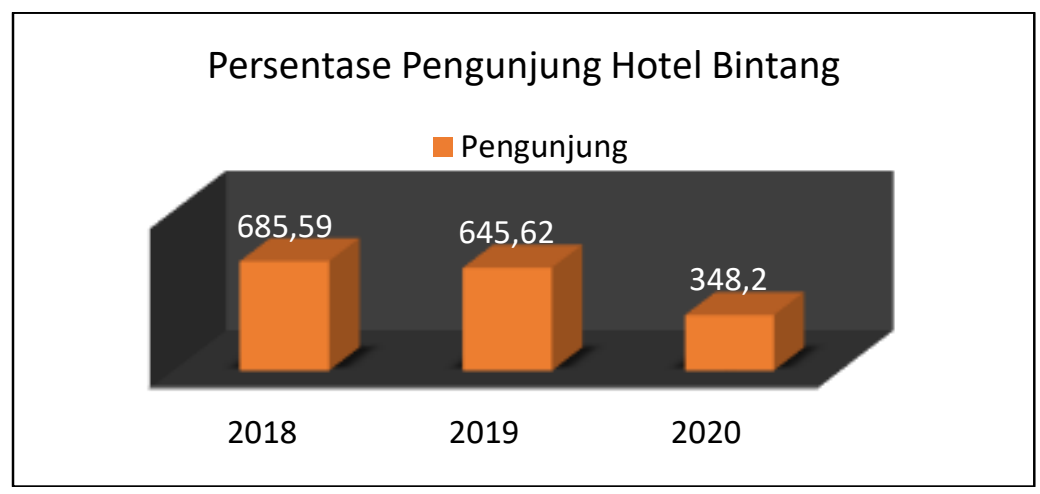

Gambar 1. Persentase pengunjung pada hotel bintang di Indonesia Sumber: Badan Pusat Statistik (BPS)

Data tersebut merupakan salah satu gambaran dampak dari adanya wabah COVID-19 bagi industri pariwisata terutama di bagian perhotelan Indonesia.

Menurut Pratiwi (2020), UMKM merupakan penyumbang terbesar terhadap PDB dan menjadi andalan dalam penyerapan tenaga kerja, sehingga pada saat krisis seperti ini pemerintah memperhatikan UMKM. Koperasi dan UMKM merupakan jenis usaha yang memiliki peran penting dalam peningkatan PDB (Pendapatan Domestik Bruto) satu negara 
khususnya di Indonesia dengan mengh adapi Era Industri 4.0 (Amri, 2020). Adanya pandemi ini membuat UMKM perlu menyesuakan diri dan meningkatkan cara pemasaran UMKM mereka. Menurut Simanjuntak dan Sukresna (2020) untuk memperoleh kinerja pemasaran yang unggul, maka yang namanya pemanfaatan teknologi yang digunakan oleh sekelompok organisasi ataupun usaha. Pemanfaatan teknologi yang dapat digunakan oleh para pelaku UMKM di Indonesia ialah dengan penerapan strategi pemasaran secara digital (digital marketing). Strategi pemasaran secara digital lebih prospektif karena memungkinkan para calon pelanggan potensial untuk memperoleh segala macam informasi mengenai produk dan bertransaksi melalui internet (Purwana et al., 2017). Selain itu pemasaran produk menggunakan digital marketing dapat menjangkau konsumennya secara langsung dan dapat menekan biaya promosi (Hardilawati, 2020).

Berdasarkan paparan sebelumnya, dalam pemulihan perekonomian di Indonesia saat ini UMKM pada sektor pariwisata pun cukup mengambil andil. Pada Provinsi Sumatera Utara, UMKM sektor pariwisata tak jarang ditemui pada setiap kabupaten yang tersebar di kawasan Danau Toba. UMKM yang tersebar di kabupaten sekitar kawasan Danau Toba ini juga merasakan dampak buruk dari pandemi COVID-19 seperti penurunan omset pendapatan yang drastis karena sepinya pengunjung, kekurangan pasokan bahan baku sampai kekurangan biaya berdasarkan pada artikel Sumatera Bisnis, 2021. Salah satu kabupaten yang berada di kawasan Danau Toba yang memiliki beberapa UMKM Pariwisata ialah Kabupaten Toba. Kabupaten Toba merupakan satu dari tujuh Kabupaten yang mengelilingi Danau Toba. Pada Pasal 14 ayat (1) dalam Undang-Undang Kepariwisataan yang termasuk ke dalam ruang lingkup usaha-usaha bidang pariwisata ialah daya tarik wisata, kawasan pariwisata, jasa transportasi, jasa perjalanan, jasa makanan dan minuman, akomodasi, hiburan dam rekreasi, penyelenggaraan pertemuan, informasi wisata, konsultan pariwisata, pramuwisata, wisata tirta, spa, dan untuk usaha-usaha pendukungnya ialah usaha cendramata, pendidikan pariwisata dan polisi pariwisata. Berikut merupakan data UMKM Pariwisata Kabupaten Toba yang tercatat pada Diperindagkop Kabupaten Toba: 


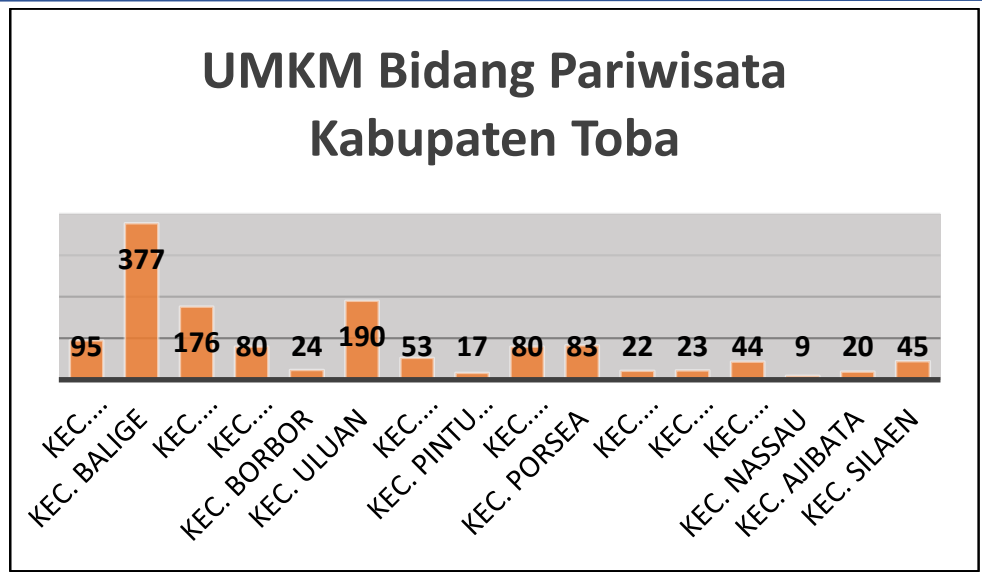

Gambar 2. Persentase UMKM Pariwisata di Kabupaten Toba Sumber: Diperindagkop Kabupaten Toba

Setelah melakukan wawancara dan observasi ke beberapa UMKM Pariwisata pada Kabupaten Toba bahwa terdapat beberapa UMKM yang tidak menerapkan strategi Digital marketing namun ada juga yang telah menerapkan strategi Digital marketing. Oleh karena itu, diperlukannya penelitian lebih mendalam mengenai pengaruh digital marketing dalam peningkatan kinerja penjualan UMKM Pariwisata Danau Toba terkhusus pada Kabupaten Toba. Berdasarkan pada Media Indonesia (2021), Kemenparekraf dan Kemenkominfo bersinergi untuk mendorong para pelaku UMKM Pariwisata menjual produk secara digital khususnya di kawasan super prioritas Danau Toba. Sehingga, asumsi saat ini bahwa masih banyak UMKM di Kabupaten Toba yang belum memahami dan menggunakan digital marketing, asumsi ini juga didukung dari adanya training tentang pemanfaatan digital bagi pelaku-pelaku UMKM di Toba yang diselenggarakan pada 16 Februari 2021 di Gedung Serba Guna Yayasan Del dan dihadiri banyak pelaku UMKM Toba termasuk UMKM bidang Pariwisata.

Penelitian ini akan dilakukan menggunakan objek penelitian yaitu UMKM Pariwisata di Kabupaten Toba telah menggunakan strategi digital marketing. Dari survey, wawancara dan observasi ke beberapa UMKM Pariwisata di Kabupaten Toba yang telah menerapkan Digital Marketing yaitu UMKM Taman Eden 100, UMKM Sekka Craft, UMKM Pizza Andaliman, UM KM Nauli Homestay, UMKM Tabo Toba, UMKM Batikta, UMKM Pizza Etnik Toba, UMKM The Boat Homestay, UMKM Toba Art Store dan UMKM Thesa Ulos, terdapat beberapa jenis digital marketing yang mereka gunakan yaitu sosial media marketing (facebook, instagram), content marketing seperti blog (website), $e$ commerce (Shopee, Tokopedia, Go-Jek, Traveloka, Air bnb), Radio Advertising (radio Del), instant messaging marketing (whatsapp, SMS, Facebook Mesengger), Television 
Advertising. Namun, dari enam jenis tersebut yang banyak digunakan dan paling sering digunakan ialah social media marketing, e-commerce dan instant messaging marketing.

Penelitian ini nantinya akan melihat bagaimana pengaruh digital marketing kepada kinerja pemasaran UMKM Pariwisata di Kabupaten Toba. Variabel dalam penelitian ini adalah social media marketing capability, e-commerce adoption, instant messaging marketing dan kinerja pemasaran. Data variabel ini nantinya yang akan diolah menggunakan Structural Equation Modeling (SEM) dengan software AMOS.

\section{METODE PELAKSANAAN}

Penelitian ini dimulai dengan melakukan observasi ke beberapa UMKM Pariwisata di Kabupaten Toba untuk mengidentifikasi masalah yang ada dan merumuskannya. Kemudian, melakukan studi literatur terkait digital marketing dan kinerja pemasaran untuk mengetahui gambaran variabel dan indikator yang akan digunakan. Kemudian melakukan interview kepada 10 UMKM Pariwisata yang telah melakukan pemasaran secara digital, ini bertujuan untuk mendapatkan variabel dan indikator yang tepat. Hasil dari studi literature dan interview tersebut dirumuskanlah indikator sebanyak 25 butir dan variabel yang digunakan ialah social media marketing capability, e-commerce adoption, instant messaging marketing, digital marketing dan kinerja pemasaran. Setelah merumuskan variabel yang digunakan selanjutnya dilakukan perumusan hipotesis. Dari perumusan hipotesis tersebut, dibuatlah kuesioner yang nantinya kuesioner ini telah melalui tahap pengujian yaitu uji expert kepada dosen, uji validitas dan uji reliabilitas. Setelah melakukan pengujian maka dilakukan pengumpulan data dengan membagikan kuesioner cetak dan online (google form) kepada 132 pelaku UMKM yang telah menerapkan digital marketing. Pada penggunaan metode SEM, ukuran sampel yang harus terpenuhi adalah minimal sebanyak 100. Pedoman dalam penentuan ukuran sampel untuk SEM berdasaran pendapat Solimun dapat dilihat sebagai berikut.

1. Apabila pendugaan parameter menggunakan metode maximum likelihood estimation maka sampel yang disarankan antara 100-200 sampel, dengan minimum sebesar 50 sampel.

2. Sebanyk 5-10 jumlah parameter yang terdapat dalam model.

3. Sama dengan 5-10 kali jumlah indikator dari seluruh variabel laten yang ada.

Indikator pada penelitian ini sebanyak 25 indikator, sesuai dengan poin ketiga maka ukuran sampel yang digunakan dalam penelitian ini adalah minimal sebanyak $5 \times 25$ yaitu 125 
sampel. Data yang sudah terkumpul dianalisis menggunakan metode SEM dengan software AMOS. Langkah-langkah analisis menggunakan metode SEM ialah sebagai berikut.

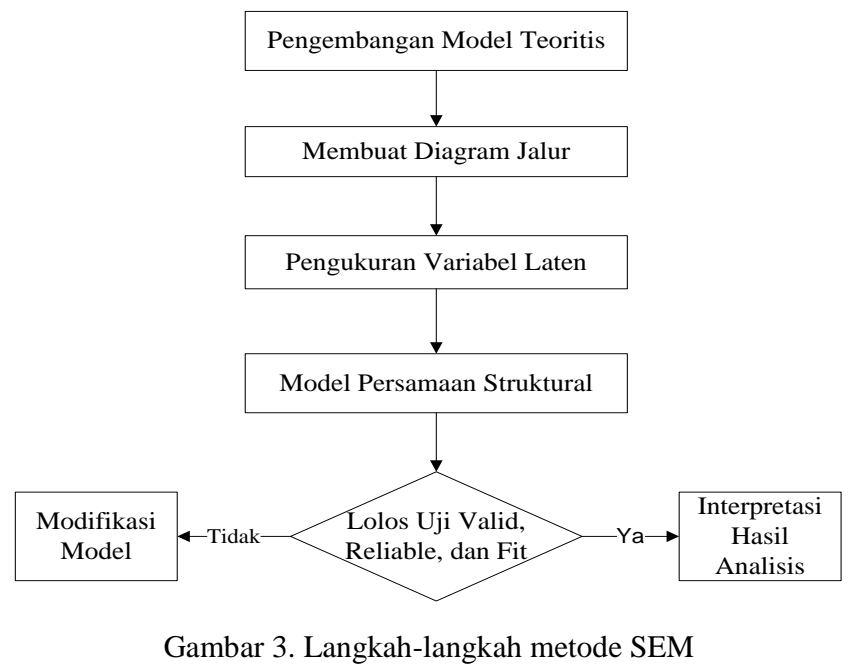

\section{Variabel Penelitian}

Penelitian ini bertujuan untuk mengetahui pengaruh dari digital marketing terhadap peningkatan kinerja pemasaran UMKM Pariwisata di Kabupaten Toba serta mengidentifikasi jenis dari pemasaran digital yang paling tepat digunakan, sehingga untuk mendapatkan variabel yang digunakan pada penelitian ini maka dilakukan studi literatur dan interview kepada pemilik, manajer dan penanggung jawab dari UMKM Pariwisata yang telah menerapkan pemasaran secara digital yaitu UMKM Taman Eden 100, UMKM Sekka Craft, UMKM Pizza Andaliman, UMKM Nauli Homestay, UMKM Tabo Toba, UMKM Batikta, UMKM Pizza Etnik Toba, UMKM The Boat Homestay, UMKM Toba Art Store dan UMKM Thesa Ulos. Setelah melakukan studi literatur terkait jenis pemasaran digital yang dapat diimplementasikan untuk meningkatkan kinerja pemasaran suatu usaha dan interview terkait jenis pemasaran digital yang telah digunakan oleh pelaku UMKM tersebut, maka ditemukan bahawa jenis pemasaran digital yang paling sering digunakan ialah social media marketing, e-commerce dan instant messaging marketing. Oleh sebab itu, yang menjadi variabel pada penelitian ini ialah :

1. Social Media Marketing Capability $\left(\mathrm{X}_{1}\right)$

Menurut Asosiasi Digital Marketing Indonesia (2019), social media marketing mengacu pada penggunaan platform media sosial untuk menarik pelanggan, dimana meliputi mendengarkan keluhan pelanggan, memulai percakapan dengan pelanggan dan berbagi informasi kepada pelanggan. Menurut Day dalam (Berliana \& Arsanti, 2018), Kapabilitas (capability) adalah proses mengaplikasi kemampuan, pengetahuan dan 
pengalaman yang dimiliki oleh sumber daya manusia untuk melaksanakan strategi pekerjaan yang telah ditetapkan dan dapat memberikan nilai bagi suatu organisasi. Berdasarkan hal tersebut, social media marketing capability dapat diartikan sebagai proses mengaplikasikan kemampuan pemasaran dengan menggunakan media sosial. Variabel social media marketing capability pada penelitian ini bertujuan untuk mengukur kecakapan ataupun kemampuan pelaku UMKM dalam menerapkan social media marketing dalam memasarkan UMKM mereka.

2. E-commerce Adoption $\left(\mathrm{X}_{2}\right)$

Menurut Choshin dan Ghaffari (2017), e-commerce dianggap sebagai strategi yang tepat untuk pemasaran, penjualan, dan integrasi layanan online yang dapat memainkan peran penting dalam mengidentifikasi, memperoleh dan mempertahankan pelanggan. Adoption merupakan proses pengambilan keputusan untuk menggunakan secara keseluruhan dari penerimaan dan penggunaan berkelanjutan dalam suatu produk, layanan maupun ide (Septiana et al., 2020). Menurut Alim \& Fitria (2020), e-commerce adoption adalah proses adopsi e-commerce yang terdiri dari serangkaian proses dan faktor adopsi. Variabel e-commerce adoption pada penelitian ini bertujuan untuk mengukur seberapa mampu pelaku UMKM mengadopsi e-commerce dalam memasarkan UMKM mereka.

3. Instant Messaging Marketing Orientation $\left(\mathrm{X}_{3}\right)$

Menurut Asosiasi Digital Marketing Indonesia (2019), instant messaging marketing merupakan media pemasaran berupa pesan singkat, seperti Whatsapp, Line, WeChat, Facebook Messenger, dan lainnya. Menurut Yuliana \& Pujiastuti (2018), marketing orientation merupakan ukuran perilaku dan aktivitas yang mencerminkan implementasi konsep pemasaran. Berdasarkan hal tersebut maka dapat disimpulkan bahwa instant messaging marketing orientation merupakan perilaku ataupun budaya pemasaran dengan menggunakan media pemasaran berupa pesan singkat. Variabel instant messaging marketing orientation pada penelitian ini bertujuan untuk mengukur perilaku pelaku UMKM dalam memasarkan UMKM mereka dengan instant messaging.

4. Kinerja Pemasaran $\left(\mathrm{Y}_{1}\right)$

Menurut Ramadhan (2018), kinerja pemasaran merupakan bagian penting dalam kinerja perusahaan secara keseluruhan menggunakan faktor untuk mengukur dampak strategi yang diterapkan. Variabel kinerja pemasaran pada penelitian ini bertujuan sebagai tolak ukur strategi pemasaran secara digital dapat meningkatkan kinerja pemasaran UMKM. 


\section{Model Hipotesis}

Penelitian ini memiliki bentuk hubungan/persamaan yang akan diuji. Berdasarkan variabel yang telah dirumuskan sebelumnya maka berikut merupakan kerangka berpikir yang menjadi dasar dari persamaan (hipotesis).

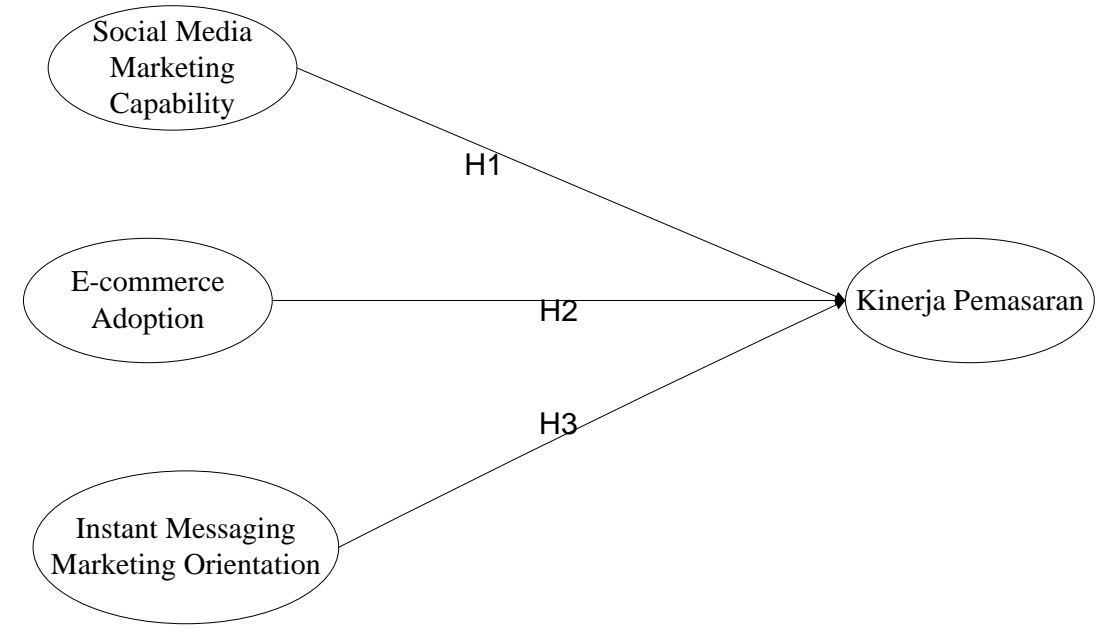

Gambar 4. Kerangka Berpikir

$\mathrm{H}_{0} \quad$ :

Digital Marketing tidak berpengaruh signifikan terhadap peningkatan Kinerja Pemasaran

$\mathrm{H}_{1}$. Social Media Marketing Capability $\left(\mathrm{X}_{1}\right)$ berpengaruh terhadap peningkatan Kinerja Pemasaran $\left(\mathrm{Y}_{1}\right)$

$\mathrm{H}_{2}$ : E-commerce Adoption $\left(\mathrm{X}_{2}\right)$ berpengaruh terhadap peningkatan Kinerja Pemasaran $\left(\mathrm{Y}_{1}\right)$

$\mathrm{H}_{3}$ : peningkatan Kinerja Pemasaran $\left(\mathrm{Y}_{1}\right)$

\section{HASIL DAN PEMBAHASAN}

\section{Gambaran Umum Responden}

Responden pada penelitian ini merupakan para pelaku UMKM Pariwisata di Kabupaten Toba yang telah menerapkan digital marketing, sebanyak 54\% merupakan karyawan, 27\% merupakan pemilik da 19\% merupakan manajer. Karakteristik umur dari responden tersebut ialah sebanyak 52\% berumur 17-25 tahun, $24 \%$ berumur 26-36 tahun, $14 \%$ berumur $37-49$ tahun, $8 \%$ berumur $50-60$ tahun dan $2 \%$ berumur $>60$ tahun dengan 
jenis kelamin sebesar $40 \%$ untuk laki-laki dan 60\% untuk perempuan. Pendidikan akhir yang diemban responden penelitian ini ialah sebesar 27\% merupakan lulusan diploma, 23\% merupakan lulusan S1-S2 dan 51\% merupakan lulusan SMA. Jenis usaha dari responden penelitian ini ialah 13\% merupakan usaha homestay, 30\% merupakan usaha kuliner, 29\% merupakan usaha souvenir dan $28 \%$ merupakan usaha fashion. Lokasi usaha dari responden ini berada di 13 Kecamatan yaitu Kec. Balige, Kec. Laguboti, Kec. Ajibata, Kec. Bonatua Lunasi, Kec. Borbor, Kec. Lumban Julu, Kec. Parmaksian, Kec. Porsea, Kec. Siantar Narumonda, Kec. Sigumpar, Kec. Silaen, Kec. Tampahan dan Kec. Uluan. Responden paling banyak berlokasi di Kec. Balige.

\section{Full Model Structural Equation Modelling}

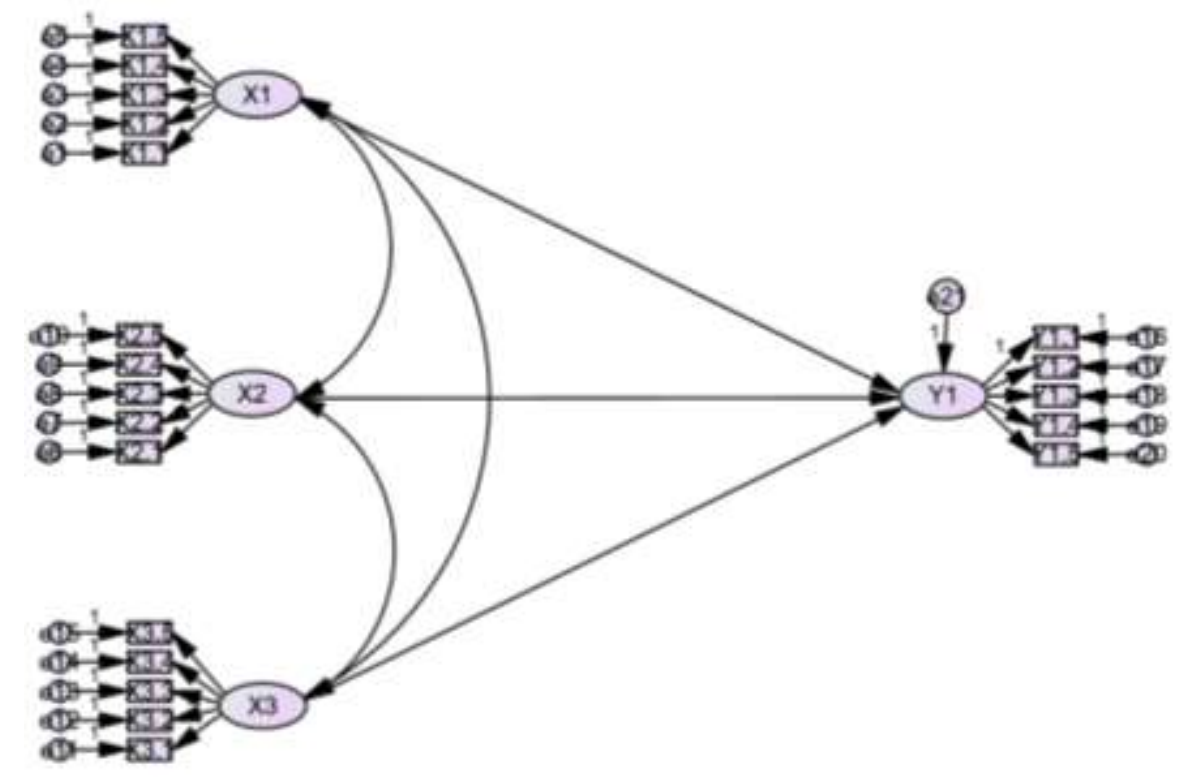

Gambar 5. Path Diagram Full Model

Gambar tersebut memperlihatkan bahwa keterkaitan antara antar variabel laten dengan variabel endogen yang nantinya diagram jalur ini dapat dikonversikan ke dalam bentuk matematis.

\section{Uji Validitas Model dan Reliabilitas Model}


Tabel 1. Uji Validitas Model dan Reliabilitas Model

\begin{tabular}{|c|c|c|c|c|c|c|c|}
\hline No & Variabel & $\begin{array}{c}\text { Indikator/ } \\
\text { Measurement }\end{array}$ & $\begin{array}{c}\text { Standardized } \\
\text { Loading Factors } \\
(\text { SLF })\end{array}$ & $\begin{array}{c}\text { Validity } \\
\text { Test }\end{array}$ & CR & AVE & $\begin{array}{c}\text { Reliability } \\
\text { Test }\end{array}$ \\
\hline \multirow{5}{*}{1} & \multirow{5}{*}{$\begin{array}{c}\text { Social } \\
\text { Media } \\
\text { Marketing } \\
\text { Capability }\end{array}$} & X1.1 & 0,655 & Valid & \multirow{5}{*}{0,667} & \multirow{5}{*}{0,832} & \multirow{5}{*}{ Reliability } \\
\hline & & $\mathrm{X} 1.2$ & 0,751 & Valid & & & \\
\hline & & $\mathrm{X} 1.3$ & 0,544 & Valid & & & \\
\hline & & $\mathrm{X} 1.4$ & 0,593 & Valid & & & \\
\hline & & $X 1.5$ & 0,602 & Valid & & & \\
\hline \multirow{5}{*}{2} & \multirow{5}{*}{$\begin{array}{c}\text { E-commerce } \\
\text { Adoption }\end{array}$} & X2.1 & 0,652 & Valid & \multirow{5}{*}{0,666} & \multirow{5}{*}{0,833} & \multirow{5}{*}{ Reliability } \\
\hline & & X2.2 & 0,579 & Valid & & & \\
\hline & & $\mathrm{X} 2.3$ & 0,576 & Valid & & & \\
\hline & & X2.4 & 0,684 & Valid & & & \\
\hline & & $X 2.5$ & 0,661 & Valid & & & \\
\hline \multirow{5}{*}{3} & \multirow{5}{*}{$\begin{array}{c}\text { Instant } \\
\text { Messaging } \\
\text { Marketing } \\
\text { Orientation }\end{array}$} & X3.1 & 0,518 & Valid & \multirow{5}{*}{0,649} & \multirow{5}{*}{0,799} & \multirow{5}{*}{ Reliability } \\
\hline & & X3.2 & 0,66 & Valid & & & \\
\hline & & X3.3 & 0,743 & Valid & & & \\
\hline & & X3.4 & 0,628 & Valid & & & \\
\hline & & X3.5 & 0,682 & Valid & & & \\
\hline \multirow{5}{*}{4} & \multirow{5}{*}{$\begin{array}{c}\text { Kinerja } \\
\text { Pemasaran }\end{array}$} & Y1.1 & 0,795 & Valid & \multirow{5}{*}{0,754} & \multirow{5}{*}{0,833} & \multirow{5}{*}{ Reliability } \\
\hline & & Y1.2 & 0,729 & Valid & & & \\
\hline & & Y1.3 & 0,821 & Valid & & & \\
\hline & & Y1.4 & 0,851 & Valid & & & \\
\hline & & Y1.5 & 0,714 & Valid & & & \\
\hline
\end{tabular}

Chin; Ghozali; Hair et al. dalam (Asbari et al., 2020), Uji validitas konvergen dilakukan dengan melihat nilai dari loading factor masing-masing indikator, bobot faktor sebesar 0,5 atau lebih dianggap mempunyai validasi yang kuat untuk menjelaskan konstruk laten. Berdasarkan output dari hasil estimasi pengukuran tersebut dapat dilihat bahwa seluruh indikator yang ada memenuhi uji validitas dibuktikan dengan seluruh indikator memiliki nilai standardized loading factors diatas 0,05 sehingga tidak ada indikator yang perlu dieliminasi.

Menurut Hair et al., dan Kuncoro dalam (Keni, 2019) suatu indikator dikatakan valid apabila nilai AVE > 0,5. Nilai construct reliability (CR) secara ideal ialah CR >0,7, namun jika nilai CR berada di antara 0,60 - 0,70 masih dapat diterima apabila validias konstruk 
(indikator) dalam model dalam status baik (Kuncono, 2013). Oleh sebab itu, berdasarkan tabel output diatas maka indikator dari penelitian ini sudah dapat dikatakan reliable .

\section{Goodness of Fit}

Tabel 2. Goodness of Fit

\begin{tabular}{|l|l|l|l|}
\hline Kriteria Indeks Ukuran & Target & Hasil Estimasi & Tingkat Kecocokan \\
\hline Chi-Square & $\mathrm{P}>0,05$ & $\begin{array}{l}\mathrm{X}^{2}=398,118 \\
\mathrm{P}=0,000\end{array}$ & Kurang Baik \\
\hline CMIN/DF & $\leq 2,00$ & 2,428 & Kurang Baik \\
\hline RMSEA & $\leq 0,08$ & 0,104 & Kurang Baik \\
\hline RMR & $\leq 0,05$ & 0,082 & Kurang Baik \\
\hline CFI & $\geq 0,09$ & 0,809 & Kurang Baik \\
\hline GFI & $\geq 0,09$ & 0,755 & Kurang Baik \\
\hline IFI & $\geq 0,09$ & 0,813 & Kurang Baik \\
\hline AGFI & $\geq 0,09$ & 0,686 & Kurang Baik \\
\hline TLI & $\geq 0,09$ & 0,779 & Kurang Baik \\
\hline
\end{tabular}

Dari tabel tersebut dapat dilihat bahwa semua kriteria dari goodness of fit tidak terpenuhi, dengan kata lain model penelitian ini tidak dapat diterima sehingga perlu dilakukannya modifikasi pada model penelitian.

\section{Modifikasi Model}

Tabel 3. Output Modifikasi Model

\begin{tabular}{|l|l|l|l|}
\hline Kriteria Indeks Ukuran & Target & Hasil Estimasi & Tingkat Kecocokan \\
\hline Chi-Square & $\mathrm{P}>0,05$ & $\begin{array}{l}\mathrm{X}^{2}=103,597 \\
\mathrm{P}=0,768\end{array}$ & Good fit \\
\hline CMIN/DF & $\leq 2,00$ & 0,901 & Good fit \\
\hline RMSEA & $\leq 0,08$ & 0,014 & Close fit \\
\hline RMR & $\leq 0,05$ & 0,041 & Good fit \\
\hline CFI & $\geq 0,09$ & 1,015 & Good fit \\
\hline GFI & $\geq 0,09$ & 0,928 & Good fit \\
\hline IFI & $\geq 0,09$ & 1,009 & Good fit \\
\hline AGFI & $\geq 0,09$ & 0,868 & Marginal fit \\
\hline TLI & $\geq 0,09$ & 1,015 & Good fit \\
\hline
\end{tabular}

Setelah selesai melakukan modifikasi pada model penelitian, dapat dilihat pada tabel bahwa goodness of fit model telah memenuhi kriteria . Terdapat 1 kriteria yang menunjukkan close fit, 1 kriteria yang menunjukkan marginal fit, sedangkan 7 kriteria menunjukkan good fit yang berarti kriteria yang telah terpenuhi sebesar $80 \%$. Oleh sebab itu, disimpulkan bahwa model penelitian ini dapat dilakukan dengan menggunakan model yang telah dimodifikasi, sehingga model tersebut diterima dan dapat dilakukan interpretasi hasil.

\section{Interpretasi Hasil Uji Hipotesis}


Uji hipotesis pada penelitian ini dilakukan dengan menganalisis nilai dari probabilitas (p) dan nilai critical ratio (CR). Hipotesis dapat diterima apabila memenuhi kriteria yaitu nilai critical ratio $(\mathrm{CR})>1,96$ dan nilai probabilitas $(\mathrm{P})<0,05$. Penelitian ini tentang pengaruh digital marketing terhadap peningkatan kinerja pemasaran UMKM Pariwisata di Kabupaten Toba, dimana terdapat tiga hipotesis, dari pengolahan tersebut didapat nilai critical ratio $(\mathrm{CR})$ dan nilai probabilitas $(\mathrm{P})$ seperti pada tabel.

\begin{tabular}{|c|c|c|c|c|c|c|}
\hline & & & Estimate & SE & CR & $\mathbf{P}$ \\
\hline $\begin{array}{l}\text { Kinerja } \\
\text { Pemasaran }\end{array}$ & $\leftarrow$ & $\begin{array}{l}\text { Social Media Marketing } \\
\text { Capability }\end{array}$ & 0,667 & 0,179 & 3,716 & $* * *$ \\
\hline $\begin{array}{l}\text { Kinerja } \\
\text { Pemasaran }\end{array}$ & $\leftarrow$ & E-commerce Adoption & 0,283 & 0,232 & 1,218 & 0,223 \\
\hline $\begin{array}{l}\text { Kinerja } \\
\text { Pemasaran }\end{array}$ & & $\begin{array}{l}\text { Instant Messaging } \\
\text { Marketing Orientation }\end{array}$ & 0,185 & 0,264 & 0,702 & 0,483 \\
\hline
\end{tabular}

Berdasarkan tabel tersebut disimpulkan bahwa terdapat satu hipotesis yang diterima yaitu

\section{$\mathrm{H}_{1}:$ Social Media Marketing Capability
peningkatan Kinerja Pemasaran $\left(\mathrm{Y}_{1}\right)$}

\section{KESIMPULAN}

Berdasarkan dari hasil pengujian, maka dapat adanya pengaruh digital marketing terhadap peningkatan kinerja pemasaran di Kabupaten Toba. Penelitian ini juga mengidentifikasi bahwa terdapat satu variabel yang mempengaruhi kinerja pemasaran ( $\left.\mathrm{Y}_{1}\right)$ UMKM Pariwisata di Kabupaten Toba yaitu social media marketing capability $\left(\mathrm{X}_{1}\right)$. Oleh sebab itu, perlu adanya pengoptimalan pemasaran penggunaan digital marketing terkhusus pada pemasaran menggunakan sosial media yang dilakukan oleh pelaku UMKM Pariwisata di Kabupaten Toba agar terjadinya pengkatan pada kinerja pemasaran UMKM. Saran untuk penelitian selanjutnya adalah untuk lebih mengerucutkan jenis UMKM Pariwisata di Kabupaten Toba yang akan dijadikan sebagai objek penelitian nantinya, misalnya menganalisis jenis pemasaran digital yang tepat bagi kinerja pemasaran UMKM Kuliner di Kabupaten Toba.

\section{UCAPAN TERIMA KASIH}

Pada penelitian ini, penulis mengucapkan terima kasih kepada dosen pembimbing Ibu Mariana Simanjuntak, dosen-dosen Manajemen Rekayasa IT Del, pihak-pihak yang 
terlibat selama pengumpulan data mulai dari dinas pariwisata dan kebudayaan Toba, dinas Koperindag Toba, dan para pelaku UMKM di Kabupaten Toba.

\section{DAFTAR PUSTAKA}

Amri, A. (2020). Dampak Covid-19 Terhadap UMKM di Indonesia. Jurnal Brand.

Asbari, M., Purwanto, A., \& Budi, P. (2020). Pengaruh Iklim Organisasi dan Kepemimpinan Transformasional Terhadap Produktivitas Kerja Inovatif Pada Industri Manufaktur di Pati Jawa Tengah . Jurnal Produktivitas, 7(1). https://doi.org/http://dx.doi.org/10.29406/jpr.v7i1.1797

Hamzah, L. M., \& Agustien, D. (2019). Pengaruh Perkembangan Usaha Mikro, Kecil, dan Menengah Terhadap Pendapatan Nasional Pada Sektor UMKM di Indonesia. Jurnal Ekonomi Pembangunan, 8, 127-135.

Hardilawati, W. laura. (2020). Strategi Bertahan UMKM di Tengah Pandemi Covid-19. Jurnal Akuntansi Dan Ekonomika. https://doi.org/10.37859/jae.v10i1.1934

Kementrian RI. (2009). Undang Undang No. 10/2009 tentang Kepariwisataan. Undang Undang No. 10/2009 Tentang Kepariwisataan.

Keni, W. K. S. D. (2019). Pengaruh Social Network Marketing (Snm) Dan Electronic Word Of Mouth (Ewom) Terhadap Minat Beli Pelanggan. Jurnal Manajemen Bisnis Dan Kewirausahaan, 2(6). https://doi.org/10.24912/jmbk.v2i6.4910

Kuncono, O. S. (2013). Analisis Model Pengukuran \& Model Persamaan Struktural.

Manik, C. (2021). Dampak Covid-19, Pedagang Suvenir di Kawasan Danau Toba Keluhkan Omzet. Bisnis Sumatra.

Patimatuzzakrah. (2020). Dampak Pariwisata Terhadap Pengembangan Dan Pendapatan Masyarakat Di Pantai Kuta Mandalika Desa Kuta Kecamatan Pujut Lombok Tengah. Universitas Muhammadiyah Mataram.

Pratiwi, M. I. (2020). DAMPAK COVID-19 TERHADAP PERLAMBATAN EKONOMI SEKTOR UMKM. Jurnal Ners, Vol.4, 30-39.

Purwana, D., Rahmi, R., \& Aditya, S. (2017). Pemanfaatan Digital Marketing Bagi Usaha Mikro, Kecil, Dan Menengah (UMKM) Di Kelurahan Malaka Sari, Duren Sawit. Jurnal Pemberdayaan Masyarakat Madani (JPMM). https://doi.org/10.21009/jpmm.001.1.01

Simanjuntak, M., \& Sukresna, I. M. (2020). Peningkatan Kinerja Pemasaran Digital Melalui Technology Acceptance Model. Prosiding The 11th Industrial Research Workshop and National Seminar, 11(1).

UMKM Danau Toba Didorong Pasarkan Produk di Platform E-Commerce. (2021). Media Indonesia.

Undang-Undang No. 20 Tahun 2008. (2008). Tentang: Usaha,Mikro,Kecil dan Menengah. Sekretariat Negara. Jakarta.

(C) 2021 by authors. Content on this article is licensed under a Creative Commons Attribution 4.0 International license. (http://creativecommons.org/licenses/by/4.0/). 